\title{
In vivo Prevention of Transplant Arteriosclerosis by ex vivo Expanded Human Regulatory T Cells
}

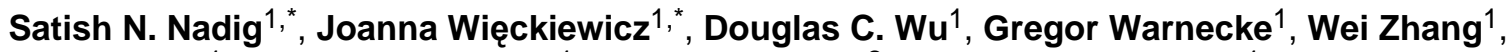 \\ Shiqiao Luo ${ }^{1}$, Alexandru Schiopu ${ }^{1}$, David P. Taggart ${ }^{2}$, and Kathryn J. Wood ${ }^{1}$ \\ ${ }^{1}$ Transplantation Research Immunology Group, Nuffield Department of Surgery, John Radcliffe \\ Hospital, University of Oxford, Oxford OX3 9DU, United Kingdom \\ ${ }^{2}$ Nuffield Department of Surgery, John Radcliffe Hospital Division of Cardiothoracic Surgery, \\ United Kingdom
}

\begin{abstract}
Transplant arteriosclerosis (TA) is the hallmark of chronic allograft dysfunction (CAD) affecting transplanted organs in the long term [1,2]. These fibroproliferative lesions lead to neointimal thickening of arteries in all transplanted allografts [2]. Luminal narrowing then leads to graft ischemia and organ demise. To date, there are no known tolerance induction strategies that prevent TA $[3,4]$. Therefore, this study was designed to test the hypothesis that human regulatory $\mathrm{T}$ cells ( $\mathrm{T}_{\text {reg }}$ cells) expanded ex vivo could prevent $\mathrm{TA}$. Here we show the comparative capacity of $\mathrm{T}_{\text {reg }}$ cells, sorted via two separate strategies, to prevent TA in a clinically relevant chimeric humanized mouse system. We found that the in vivo development of TA in human arteries was prevented with the treatment of ex vivo expanded human $\mathrm{T}_{\text {reg }}$ cells. Additionally, we show that $\mathrm{T}_{\text {reg }}$ cells sorted based on the low expression of CD127 (IL-7Ra) provide a more potent therapy to conventional $\mathrm{T}_{\text {reg }}$ cells. Our results demonstrate, for the first time, that human $\mathrm{T}_{\text {reg }}$ cells can inhibit TA by impairing effector function and graft infiltration. We anticipate our findings to serve as a foundation for the clinical development of therapeutics targeting TA in both allograft transplantation and other immune-mediated causes of vasculopathy [5].
\end{abstract}

Investigating the mechanisms driving the development of TA in situ in transplant recipients is challenging. While protocol biopsies and intravascular imaging provide snapshots of the process and enable the evolution of CAD to be described[6,7], the development of a chimeric humanized mouse system has enabled the mechanisms and impact of novel interventions to be studied in vivo[8]. Allogeneic peripheral blood mononuclear cells (PBMC) were found to elicit immune-mediated rejection of transplanted human arterial segments mimicking the TA seen in human transplantation. Interestingly, IFN- $\gamma$ elicited the same response in the absence of leukocytes[8], supporting the concept that both immune and non-immune mechanisms contribute to the process. In this report, we investigated the possibility of attenuating the fibroproliferative lesions seen with TA using ex vivo expanded human $\mathrm{T}_{\text {reg }}$ cellular therapy, compared the capacity of $\mathrm{CD} 25^{\mathrm{hi}} \mathrm{CD} 4^{+}$vs.

$\mathrm{CD} 127^{\mathrm{lo}} \mathrm{CD} 25^{+} \mathrm{CD} 4^{+}$cells to suppress allogeneic immune responses, and evaluated the impact of $\mathrm{T}_{\text {reg }}$ cells on IFN- $\gamma$ production.

Correspondence should be addressed to KJW (kathryn.wood@nds.ox.ac.uk).

* SNN and JW contributed equally to this text

Author Contributions SNN, JW, GW, and KJW designed the experiments; SNN and JW performed the experiments and analyzed the data; DCW, GW, WZ, SL, and AS assisted with the experiments; DT provided expertise and advice along with human tissue; and SNN, JW, and KJW wrote the manuscript.

Competing financial interest policy - Authors declare no competing financial interest 
Human $\mathrm{T}_{\text {reg }}$ cells were FACS-sorted from healthy donor PBMC as $\mathrm{CD} 25^{\text {hi }} \mathrm{CD} 4{ }^{+}$cells (designated $\mathrm{CD} 25^{\mathrm{hi}}$ ) or $\mathrm{CD} 127^{\mathrm{lo}} \mathrm{CD} 25^{+} \mathrm{CD} 4^{+}$cells (designated $\mathrm{CD} 127^{\mathrm{lo}}$ ) to greater than 94\% purity ( $n=5$ independent experiments; Supplementary Fig. 1a). After sorting, the cells were expanded in vitro using beads coated with CD3 and CD28-specific antibodies and recombinant human IL-2 (Fig. 1a) $[9,10]$. Both populations consistently expanded to greater than 600-fold ( $\mathrm{n}=5$ expansions; Supplementary Fig. $1 \mathrm{~b}$ ). After expansion, both subsets retained expression of $\mathrm{T}_{\text {reg }}$ cell markers including CD25, FoxP3, GITR, CTLA-4 (Fig. 1b,c and Supplementary Fig. 1c)[11]. Interestingly, significant differences were observed in the expression of CD127, CD62L and CD27. Moreover, in vitro suppression assays consistently revealed a higher suppressive capacity in $\mathrm{CD} 127^{\mathrm{lo}}$ sorted cells towards allo-stimulated autologous PBMC $(n=5)$ as well as $\mathrm{CD} 25^{-} \mathrm{CD} 4^{+}$effector cells $(n=3)$ after expansion (Fig. $1 \mathrm{~d}, \mathrm{e})$. Expanded CD127 ${ }^{\mathrm{lo}}$ cells expressing CD62L and CD27 suppressed PBMC much more efficiently than cells expressing low levels of CD62L, CD27, or both (Fig. 1f). The molecular mechanism of suppression by expanded $\mathrm{T}_{\text {reg }}$ cells in vitro was not dependent on IL-10 or CTLA-4 (Supplementary Fig. 2a) and required cell-cell contact (Supplementary Fig. 2b). Moreover, both $\mathrm{CD} 25^{\text {hi }} \mathrm{CD} 4^{+}$and $\mathrm{CD} 127^{\mathrm{lo}} \mathrm{CD} 4^{+}$expanded $\mathrm{T}_{\text {reg }}$ cells inhibited dendritic cell maturation as demonstrated by the reduced increase in CD86 expression (Supplementary Fig $2 \mathrm{c}, \mathrm{d}$ ). Importantly, the expanded $\mathrm{T}_{\text {reg }}$ populations could be frozen for storage without loss of functional activity (Supplementary Fig. 3a) and exerted their suppressive ability even over HLA-mismatched PBMC (Supplementary Fig. 3b).

Next, the functional activity of the $\mathrm{CD} 25^{\mathrm{hi}} \mathrm{CD} 4^{+}$and $\mathrm{CD} 127^{\mathrm{lo}} \mathrm{CD} 4^{+}$expanded cells, from five separate PBMC donors, was tested in vivo. Human internal mammary arterial (IMA) sidebranches, procured from patients undergoing coronary artery bypass surgery, were

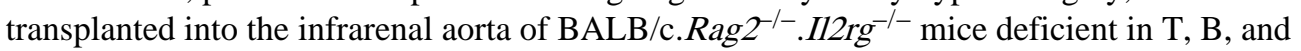
NK cells. The following day $10 \times 10^{6}$ allogeneic or autologous PBMC were used to inoculate mice bearing human arterial grafts. Transplanted human arterial grafts were maximally dilated and harvested 30 days after transplantation (Fig. 2a). In mice reconstituted with allogeneic PBMC (defined as $>1 \%$ splenic human leukocyte chimerism; Supplementary Fig. 4) a significant vascular intimal hyperplasia and a decrease in luminal diameter was observed in the transplanted vessels as compared to that of vessels transplanted into animals that either did not receive human PBMC, or those reconstituted with PBMC autologous to the arterial graft (Fig. 2b-e; Supplementary Table 1). Importantly, the neointimal proliferation seen in rejecting arterial grafts was allo-specific to the human vessel as the native mouse aorta prior to the suture line was not affected (Supplementary Fig. 5a). Moreover, xeno-responses were confirmed to play only a minor role in this system as evidenced by in vitro mixed lymphocyte reactions (MLR); wherein, allo-human responses predominated over any and all xeno-responses (Supplementary Fig. 5b). In vitro analysis of precursor frequency, measured by IFN- $\gamma$ ELISPOT or proliferation, demonstrated increased frequency of donor alloantigen specific responding cells upon restimulation, irrespective of the presence or absence of mouse splenocytes (Fig. 2f,g).

We then reconstituted mice transplanted with human vessels with human PBMC and ex vivo expanded CD25 $5^{\mathrm{hi}}$ or $\mathrm{CD} 127^{\mathrm{lo}}$ cells from the same allogeneic blood donor at a 1:1 ratio. Here we show that both $\mathrm{CD} 25^{\mathrm{hi}}$ and $\mathrm{CD} 127^{\mathrm{lo}}$ populations have a significant impact on the development of TA in vivo without inhibiting the rate of reconstitution (Fig. $2 \mathrm{~h}-\mathrm{j}$ and Supplementary Fig. 4b-d). Analysis of vessels transplanted into mice reconstituted with human $\mathrm{T}_{\text {reg }}$ cells only was not feasible as the level of reconstitution achieved using fractionated $\mathrm{CD}^{+} \mathrm{T}$ cells alone was $<1 \%$ (data not shown). The vasculopathy seen in chimeric humanized mice treated with $\mathrm{CD} 25^{\mathrm{hi}} \mathrm{T}_{\text {reg }}$ cellular therapy was significantly less than that in mice reconstituted with allo-PBMC alone $(P=0.013)$; however, TA is still evident in these grafts at varying degrees (Fig. $2 \mathrm{~h}, \mathrm{j})$. In contrast, animals treated with $\mathrm{CD} 127^{\mathrm{lo}}$ ex vivo expanded $\mathrm{T}_{\text {reg }}$ cells reveal almost complete abrogation of TA without such 
variation between different PBMC and vessel donors, corroborating our in vitro results (Fig. 1 and Fig. $2 \mathrm{i}, \mathrm{j}$ ). Moreover, in the presence of $\mathrm{T}_{\text {reg }}$ cell therapy IFN- $\gamma$ production is markedly diminished when compared to stimulation of PBMC alone with alloantigen either in vivo (Fig. 3a,b and Supplementary Fig. 6a) or in vitro (Fig. 3c and Supplementary Fig. $6 b)$.

The ability of $\mathrm{T}_{\text {reg }}$ cells to inhibit the secretion of IFN- $\gamma$ in vivo, thought to be integral to the development of TA $[8,12,13]$, was confirmed by testing serum samples procured from human leukocyte engrafted mice; upregulation of human IFN- $\gamma$ by human PBMC alone was substantially inhibited by CD127 ${ }^{\text {lo }} \mathrm{T}_{\text {reg }}$ cellular therapy (Fig. 3a). Importantly, the expression of IFN- $\gamma$ within the graft itself was also significantly inhibited by treatment with $\mathrm{CD} 127^{\mathrm{lo}} \mathrm{T}_{\text {reg }}$ cells as indicated by real-time PCR analysis (Fig. $3 \mathrm{~b} ; P<0.01$ ). Suppression of IFN- $\gamma$ expression within the allograft correlated with increased detection of intragraft FOXP3 mRNA in animals treated with CD127 $7^{\text {lo }} \mathrm{T}_{\text {reg }}$ cells (Fig. $3 \mathrm{~b}$ ), indicating that CD127 $7^{\mathrm{lo}}$ $\mathrm{T}_{\text {reg }}$ cells may infiltrate the graft. Histological assessment revealed that virtually all human graft infiltrating cells were $\mathrm{CD}^{+} \mathrm{T}$ cells $\left(854 \pm 280 \mathrm{hCD}^{+} 5^{+}\right.$versus $845 \pm 318 \mathrm{hCD}^{+}$in the neointima in the PBMC group; mean \pm SD). Notably, human CD4 and CD8 infiltration of both the graft adventitia and neointima[14] was markedly decreased in mice treated with $\mathrm{PBMC}+\mathrm{CD} 127^{\text {lo }} \mathrm{T}_{\text {reg }}$ cell therapy compared to that in mice reconstituted with PBMC alone or with PBMC $+\mathrm{CD} 25^{\text {hi }}$ cells (Fig. 3d). Taken together, these data suggest that treatment with $\mathrm{T}_{\text {reg }}$ cells may inhibit the development of TA by preventing the effector response of PBMC and mobilization of IFN- $\gamma$ producing cells to an allograft $[15,16]$.

We then investigated the potency of CD127 ${ }^{\mathrm{lo}} \mathrm{T}_{\text {reg }}$ cells on the development of TA in the human-mouse chimera. Interestingly, when $2 \times 10^{6} \mathrm{CD} 127^{\text {lo }} \mathrm{T}_{\text {reg }}$ cells were transferred with $10 \times 10^{6}$ PBMC, we also observed a significant decrease in the development of arteriosclerotic disease when compared to transplanted animals inoculated with PBMC alone (Fig. 4 a-c,e; $P<0.05$ ). However, the efficacy of regulation was lost when $1 \times 10^{6} \mathrm{CD} 127^{\text {lo }}$ $\mathrm{T}_{\text {reg }}$ cells were co-transferred with $10 \times 10^{6} \mathrm{PBMC}$ (Fig. $4 \mathrm{~d}$ ). The level of TA seen in animals receiving five-fold less $\mathrm{CD} 127^{\mathrm{lo}} \mathrm{T}_{\text {reg }}$ cells was similar to that of animals receiving $\mathrm{PBMC}+\mathrm{CD} 25^{\text {hi }} \mathrm{T}_{\text {reg }}$ cells at a 1:1 ratio (Fig. 4f). Additionally, $\mathrm{CD}^{+}$and $\mathrm{CD} 8^{+}$ lymphocytes produced less IFN- $\gamma$ in vitro when co-cultured with $C D 127^{l o} \mathrm{~T}_{\text {reg }}$ cells at a 1:1 and a 1:1/5 ratio confirming the increased potency of CD127 ${ }^{\mathrm{lo}} \mathrm{T}_{\text {reg }}$ cells (Fig. $4 \mathrm{~g}$ ). Taken together, these data suggest that titrated levels of ex vivo expanded $\mathrm{T}_{\text {reg }}$ cells sorted based on $\mathrm{CD} 127^{\mathrm{lo}}$ expression are five fold more potent than that of $\mathrm{CD} 25^{\mathrm{hi}} \mathrm{T}_{\text {reg }}$ cells.

These data demonstrate the unique ability of ex vivo expanded human $\mathrm{T}_{\text {reg }}$ cells to successfully abrogate the development of TA in vivo. Over the past decade, both thymus derived and antigen induced $\mathrm{T}_{\text {reg }}$ cells, initially identified by Sakaguchi et. al., as $\mathrm{CD} 25^{+} \mathrm{CD} 4^{+}$, have been highlighted for their suppressive capabilities in vitro and in vivo $[11,17,18]$ and therapeutic potential in the regulation of autoimmunity, allergy and immune-mediated transplant rejection. Although, the results presented here are promising and exciting, they must also be interpreted with caution. As seen in Supplementary Fig. 7, mice treated with $\mathrm{T}_{\text {reg }}$ cell therapy lose medial architecture in the graft when compared to native arterial sections or animals treated with PBMC alone.

Therefore, translation to the clinic, is likely dependent upon the isolation of pure populations of suppressive cells that can reproducibly and safely abrogate disease. Critical to this process is the identification of markers that permit the isolation and enrichment of viable $\mathrm{T}_{\text {reg }}$ cells for therapeutic transfer. The recent observation of the inverse correlation between the IL-7 Ra (CD127) subunit and the suppressive capacity of CD25 ${ }^{\text {hi }} \mathrm{CD} 4{ }^{+} \mathrm{T}_{\text {reg }}$ cells allows for an additional potential target to isolate and expand cells with increased suppressive function ex vivo[19-21]. In mouse models, only the subpopulation of $\mathrm{CD} 25^{+} \mathrm{CD} 4^{+} \mathrm{T}_{\text {reg }}$ cells 
expressing CD62 $\mathrm{L}^{+}$were found responsible for protection against lethal acute GVHD[22].

Therefore, the higher expression of CD62L on the ex vivo expanded CD127 $7^{\text {lo }} \mathrm{T}_{\text {reg }}$ cells used here may be advantageous in clinical situations allowing for more efficient homing to secondary lymph nodes, as well as in the chimeric humanized in vivo model used here, based on the high conservation of the CD62L molecule between species[23]. Additionally, the downregulation of the IL-7Ra along with the upregulation of CD27 (Fig. 1) have been correlated previously to a highly suppressive subset of $\mathrm{T}_{\text {reg }}$ cells believed to exert their effects locally (i.e. allograft or draining lymph node) rather than re-circulating systemically[19,24]. The paradigm of disease that has been proposed to explain development of TA is one of local effector cell-mediated recruitment of rapidly proliferating vascular smooth muscle cells leading to neointimal formation and arterial luminal occlusion[3]. With our findings, it seems that immunoregulation of these locally destructive effector cells may be feasible with the use of $\mathrm{T}_{\text {reg }}$ cellular therapy. However, further tests of the efficacy and safety of these cells are essential.

\section{Methods}

Mice

We obtained BALB/c.rag $2^{-/} . I 12 \mathrm{rg}^{-/-}\left(\mathrm{H}_{2}{ }^{\mathrm{d}}\right)$ mice from Charles River Laboratories and housed the animals under specific pathogen-free conditions. We performed all experiments using protocols approved by the Committee on Animal Care and Ethical Review at Oxford University and in accordance with the UK Animals (Scientific Procedures) Act 1986. We used mice between the ages of 6-10 weeks.

The vast majority of mice (over 75\%) reconstituted with human PBMC showed $>1 \%$ splenic engraftment defined as fully reconstituted. The level of reconstitution was routinely over $10 \%$ and did not correlate with amount of arteriosclerosis seen (SNN, GW, KJW unpublished observations).

\section{Procurement of human arterial side branches}

We obtained perforating side branches of the IMA during procurement of the left and right IMA in a skeletonized fashion and immediately placed in a $4.0 \%$ phenoxybenzamine and normal saline solution[25]. Human tissue used for this study was obtained under the ethical reference number 04/Q1605/89. Study was approved by UK National Research Ethics Service, Oxfordshire REC B. Informed consent was obtained from all patients.

\section{Aortic interposition grafting}

Aortic interposition grafts were performed with human IMA sidebrancehes into the abdominal aorta of BALB/c.rag $2^{-/} . I 12 \mathrm{rg}^{-/-}$mice with an end-to end anastomosis using a technique described by Koulack et al.[26]

\section{Sorting and expansion of human CD25 ${ }^{\mathrm{hi}} \mathrm{T}$ cells and CD127 ${ }^{\mathrm{lo}} \mathrm{T}$ cells}

We isolated PBMC from buffy coats provided by the National Blood Service (NBS) by Ficoll-Paque (GE Healthcare) gradient centrifugation. $\mathrm{CD}^{+} \mathrm{T}$ cells were then enriched using the Human $\mathrm{CD}^{+}$Lymphocyte Enrichment Set (BD), stained with appropriate antibodies (CD4 APC and CD25 PE or CD127 PE, CD25 APC and CD4 PerCP, all BD) and sorted using a BD FacsARIA cell sorter (BD). CD4 ${ }^{+} \mathrm{T}$ cells expressing high levels of CD25 $\left(\mathrm{CD} 25^{\text {hi }} \mathrm{CD} 4^{+}\right)$and low levels of $\mathrm{CD} 127\left(\mathrm{CD} 127^{\mathrm{lo}} \mathrm{CD} 25^{+} \mathrm{CD} 4^{+}\right)$were subsequently sorted and recovered. In a limited number of experiments we stained whole PBMC for sorting giving a similar purity after each sort (more than 96\%). Cells were cultured in RPMI 1640 media supplemented with L-glutamine, penicillin/streptomycin, sodium pyruvate and $10 \%$ of human $\mathrm{AB}$ pooled serum. For expansion, sorted cells were cultured in the presence of 
recombinant human IL-2 (1,000 $\left.\mathrm{U} \mathrm{ml}^{-1}\right)$ (Chiron) and Human T-Expander CD3/CD28 Dynabeads (Invitrogen) in a 1:2 cell per bead ratio for two rounds of expansion, 7 days each. After the second round of expansion, beads were removed and cells were silenced for 2 days in medium containing $200 \mathrm{U} \mathrm{ml}^{-1}$ of IL-2 (Fig. 1a). After each expansion, the phenotype of cells were assessed by staining for FoxP3 (eBiosciences), GITR (R\&D Systems) CD25, CTLA-4, CD127, CD27 and CD62L (BD).

\section{Flow cytometry}

Analysis of in vivo experiments on post-operative day 30: We generated single cell suspensions from spleen and performed a red cell lysis was performed. For phenotypic analysis, antibodies against human CD3 (eBioscience), CD4 (Caltag), CD8, CD25, CD45, and CD127 (BD) were used.

Intracellular cytokine staining-For cytokine analysis, cells were stimulated with irradiated allogeneic PBMC for 5 days and re-stimulated for $5 \mathrm{~h}$ with phorbol 12-myristate 13-acetate (PMA, $100 \mathrm{ng} \mathrm{ml}^{-1}$, Sigma), ionomycin $\left(1 \mu \mathrm{g} \mathrm{ml}^{-1}\right.$, Sigma) and monensin (GolgiStop, $1 \mu \mathrm{ml}^{-1}$, BD) before being stained with antibodies to CD4, CD8, CD3 (BD), and the viability dye 7-AAD (eBiosciences). We then fixed and permeabilized cells and stained with antibody to intracellular IFN- $\gamma(\mathrm{BD})$. .

\section{In vitro suppression assays}

We tested the suppressive activity of expanded $\mathrm{CD} 25^{\text {hi }}$ or $\mathrm{CD} 127^{\text {lo }}$ cells by using an in vitro suppression assays. Autologous PBMC $\left(1 \times 10^{5}\right)$ were incubated with irradiated allogeneic PBMC $\left(1 \times 10^{5}\right)$ and varying numbers of expanded CD25 hi or CD127 lo cells. We then assessed proliferation after 7 days by addition of ${ }^{3} \mathrm{H}$-thymidine for the last $16 \mathrm{~h}$ of culture.

\section{Adoptive transfer of human cells}

In all experiments, human PBMC were obtained from random donors and the data pooled. $10 \times 10^{6}$ Ficoll-Paque purified human PBMC were injected intraperitoneally into recipient mice. Alternatively, human PBMC were adoptively transferred in the same fashion with an equal number of $\mathrm{CD} 25^{\mathrm{hi}}$ or $\mathrm{CD} 127^{\mathrm{lo}}$ ex vivo expanded human T cells. In the described titration experiments, $2 \times 10^{6} \mathrm{CD} 127^{\mathrm{lo}}$ or $1 \times 10^{6} \mathrm{CD} 127^{\mathrm{lo}}$ were co-transferred with $10 \times$ $10^{6}$ PBMC.

\section{ELISA for human IFN-Y}

As per manufacturer's protocol (eBioscience ELISA Ready-SET-Go! Kit)

\section{Cytokine Bead Array}

Cytokine multiplex for the following $\mathrm{T}_{\mathrm{H}} 1$ and $\mathrm{T}_{\mathrm{H}} 2$ cytokines were stained for using two color (PE and FITC) bead array systems manufactured by Bender Medsystems (Vienna, Austria). The assay was carried out using manufacturer's protocols. Cytokines detected were: IL-6, IL-8, IL-10, IL-2, IFN- $\gamma$, IL-12p70, TNF- $\beta$, TNF- $\alpha$, IL-5, and IL-4.

\section{ELISPOT}

We performed IFN- $\gamma$ ELISPOT (BD Biosciences) in 3-6 repeats with $5 \times 10^{4}$ responder cells and $1 \times 10^{5}$ irradiated stimulatory cells per well incubated for $15 \mathrm{~h}$. The assay was carried out following manufacturer's protocol. 


\section{Real-time RT-PCR}

Total RNA was isolated from arterial grafts using NucleoSpin RNA XS kit (Fisher Scientific) and followed by cDNA synthesis using High Capacity RNA-to-cDNA kit (Applied Biosystems). Real-time quantification was performed using Stratagene Mx3000P (Agilent Technologies) using the HPRT probe and primers as described in [27] and TaqMan Gene Expression Assays (Applied Biosystems) for IFN- $\gamma$ and FOXP3. Quantification of the gene of interest was given by $\Delta \mathrm{Ct}$ method.

\section{Histology}

After thirty days post transplantation, we procured aortic grafts which were then snapfrozen in OCT embedding medium prior to cryostat sectioning at a thickness of 6-10 $\mu \mathrm{m}$. After drying, sections were fixed in $100 \%$ acetone for $10 \mathrm{~min}$ at $4{ }^{\circ} \mathrm{C}$ and stored in $-80{ }^{\circ} \mathrm{C}$ until further use. We then blocked all sections with $10 \%$ BSA and $5 \%$ mouse serum at room temperature for $30 \mathrm{~min}$. Primary antibodies, mouse anti-human CD4 (BD) and mouse antihuman CD8 (BD) were then applied. Following several washes, HRP-conjugated secondary antibody (DAKO Cytomation) was applied, and sections were visualized with diaminobenzidene (Sigma).

\section{Computational and statistical analyses}

We analysed data from mice displaying $>1 \%$ human $\mathrm{CD} 45^{+}$live leukocytes in the spleen as measured by flow cytometry. Morphometric analysis of transplant arteriosclerosis on EvGstained sections were measured as described[18]. Briefly, percentage intimal expansion (IE) was calculated using the following formula: $\%$ intimal expansion $=\left(\mathbf{A}_{\mathbf{I}^{-}} \mathbf{A}_{\mathbf{L}} / \mathbf{A}_{\mathbf{I}}\right) \times \mathbf{1 0 0}$; where $A_{I}$ is the area within the internal elastic lamina and $A_{L}$ is the luminal area.

Statistical evaluations were performed using Graphpad Prism software. Statistical significance was determined using Mann-Whitney $U$ test. $P<0.05$ was considered statistically significant.

\section{Supplementary Material}

Refer to Web version on PubMed Central for supplementary material.

\section{Acknowledgments}

We thank the staff of the Biomedical Services Unit at the John Radcliffe Hospital for expert animal care; M. Barnardo and the staff at the Clinical Transplant Immunology Laboratory, The Oxford Transplant Centre for molecular HLA typing; M. Carvalho-Gaspar for advice on real-time PCR; F. Issa and R. Goto for assistance with some experiments; A. Bushell and N. Jones for valuable discussions. The cardiac surgical registrars and operating theatre staff for assistance with the procurement of vessels. This work was supported by grants from The Wellcome Trust, European Union Integrated Project, RISET (www.RISETfp6.org), Medical Research Council UK and Garfield Weston Trust. SNN is an International Society for Heart and Lung Transplantation Research Fellow; JW is a RISET investigator, GW is a DFG Fellow; WZ was supported by an unrestricted grant from Becton Dickinson; AS was supported by the Swedish Heart and Lung Foundation and the Swedish Research Council.

\section{References}

1. Pucci AM, Forbes RD, Billingham ME. Pathologic features in long-term cardiac allografts. J Heart Transplant. 1990; 9:339-345. [PubMed: 2398426]

2. Hillebrands JL, Rozing J. Chronic transplant dysfunction and transplant arteriosclerosis: new insights into underlying mechanisms. Expert Rev Mol Med. 2003; 2003:1-23. [PubMed: 14987399]

3. Mitchell RN, Lichtman AH. The link between IFN-gamma and allograft arteriopathy: is the answer NO? J Clin Invest. 2004; 114:762-764. [PubMed: 15372099] 
4. Taylor DO, et al. Registry of the International Society for Heart and Lung Transplantation: twentythird official adult heart transplantation report--2006. J Heart Lung Transplant. 2006; 25:869-879. [PubMed: 16890107]

5. Tullius SG, et al. Contribution of early acute rejection episodes to chronic rejection in a rat kidney retransplantation model. Kidney Int. 1998; 53:465-472. [PubMed: 9461108]

6. Nankivell BJ, Borrows RJ, Fung CL, O'Connell PJ, Allen RD, Chapman JR. The natural history of chronic allograft nephropathy. N Engl J Med. 2003; 349:2326-2333. [PubMed: 14668458]

7. Kobashigawa JA, et al. Multicenter intravascular ultrasound validation study among heart transplant recipients: outcomes after five years. J Am Coll Cardiol. 2005; 45:1532-1537. [PubMed: 15862430]

8. Tellides G, et al. Interferon-gamma elicits arteriosclerosis in the absence of leukocytes. Nature. 2000; 403:207-211. [PubMed: 10646607]

9. Godfrey WR, et al. In vitro-expanded human CD4(+)CD25(+) T-regulatory cells can markedly inhibit allogeneic dendritic cell-stimulated MLR cultures. Blood. 2004; 104:453-461. [PubMed: 15031211]

10. Hoffmann P, Eder R, Kunz-Schughart LA, Andreesen R, Edinger M. Large-scale in vitro expansion of polyclonal human CD4(+)CD25high regulatory T cells. Blood. 2004; 104:895-903. [PubMed: 15090447]

11. Wood KJ, Sakaguchi S. Regulatory T cells in transplantation tolerance. Nat Rev Immunol. 2003; 3:199-210. [PubMed: 12658268]

12. Wang Y, et al. Interferon-gamma induces human vascular smooth muscle cell proliferation and intimal expansion by phosphatidylinositol 3-kinase dependent mammalian target of rapamycin raptor complex 1 activation. Circ Res. 2007; 101:560-569. [PubMed: 17656678]

13. Tellides G, Pober JS. Interferon-gamma axis in graft arteriosclerosis. Circ Res. 2007; 100:622632. [PubMed: 17363708]

14. Cuffy MC, et al. Induction of indoleamine 2,3-dioxygenase in vascular smooth muscle cells by interferon-gamma contributes to medial immunoprivilege. J Immunol. 2007; 179:5246-5254. [PubMed: 17911610]

15. Oberle N, Eberhardt N, Falk CS, Krammer PH, Suri-Payer E. Rapid suppression of cytokine transcription in human CD4+CD25 T cells by CD4+Foxp3+ regulatory T cells: independence of IL-2 consumption, TGF-beta, and various inhibitors of TCR signaling. J Immunol. 2007; 179:3578-3587. [PubMed: 17785792]

16. Lin CY, Graca L, Cobbold SP, Waldmann H. Dominant transplantation tolerance impairs CD8+ T cell function but not expansion. Nat Immunol. 2002; 3:1208-1213. [PubMed: 12415266]

17. Sakaguchi S, Sakaguchi N, Asano M, Itoh M, Toda M. Immunologic self-tolerance maintained by activated T cells expressing IL-2 receptor alpha-chains (CD25). Breakdown of a single mechanism of self-tolerance causes various autoimmune diseases. J Immunol. 1995; 155:1151-1164. [PubMed: 7636184]

18. Warnecke G, Bushell A, Nadig SN, Wood KJ. Regulation of transplant arteriosclerosis by CD25+CD4+ T cells generated to alloantigen in vivo. Transplantation. 2007; 83:1459-1465. [PubMed: 17565319]

19. Liu W, et al. CD127 expression inversely correlates with FoxP3 and suppressive function of human CD4+ T reg cells. J Exp Med. 2006; 203:1701-1711. [PubMed: 16818678]

20. Seddiki N, et al. Expression of interleukin (IL)-2 and IL-7 receptors discriminates between human regulatory and activated T cells. J Exp Med. 2006; 203:1693-1700. [PubMed: 16818676]

21. Putnam AL, et al. Expansion of Human Regulatory T Cells from Patients with Type 1 Diabetes. Diabetes. 2008; 58:652-662. [PubMed: 19074986]

22. Ermann J, et al. Only the CD62L+ subpopulation of CD4+CD25+ regulatory T cells protects from lethal acute GVHD. Blood. 2005; 105:2220-2226. [PubMed: 15546950]

23. Jutila MA, Watts G, Walcheck B, Kansas GS. Characterization of a functionally important and evolutionarily well-conserved epitope mapped to the short consensus repeats of E-selectin and Lselectin. J Exp Med. 1992; 175:1565-1573. [PubMed: 1375266] 
24. Koenen HJ, Fasse E, Joosten I. CD27/CFSE-based ex vivo selection of highly suppressive alloantigen-specific human regulatory T cells. J Immunol. 2005; 174:7573-7583. [PubMed: 15944257]

25. Mussa S, Choudhary BP, Taggart DP. Radial artery conduits for coronary artery bypass grafting: current perspective. J Thorac Cardiovasc Surg. 2005; 129:250-253. [PubMed: 15678032]

26. Koulack J, et al. Development of a mouse aortic transplant model of chronic rejection. Microsurgery. 1995; 16:110-113. [PubMed: 7783601]

27. Trzonkowski P, et al. Homeostatic repopulation by CD28-CD8+ T cells in alemtuzumab-depleted kidney transplant recipients treated with reduced immunosuppression. Am J Transplant. 2008; 8:338-347. [PubMed: 18211507] 


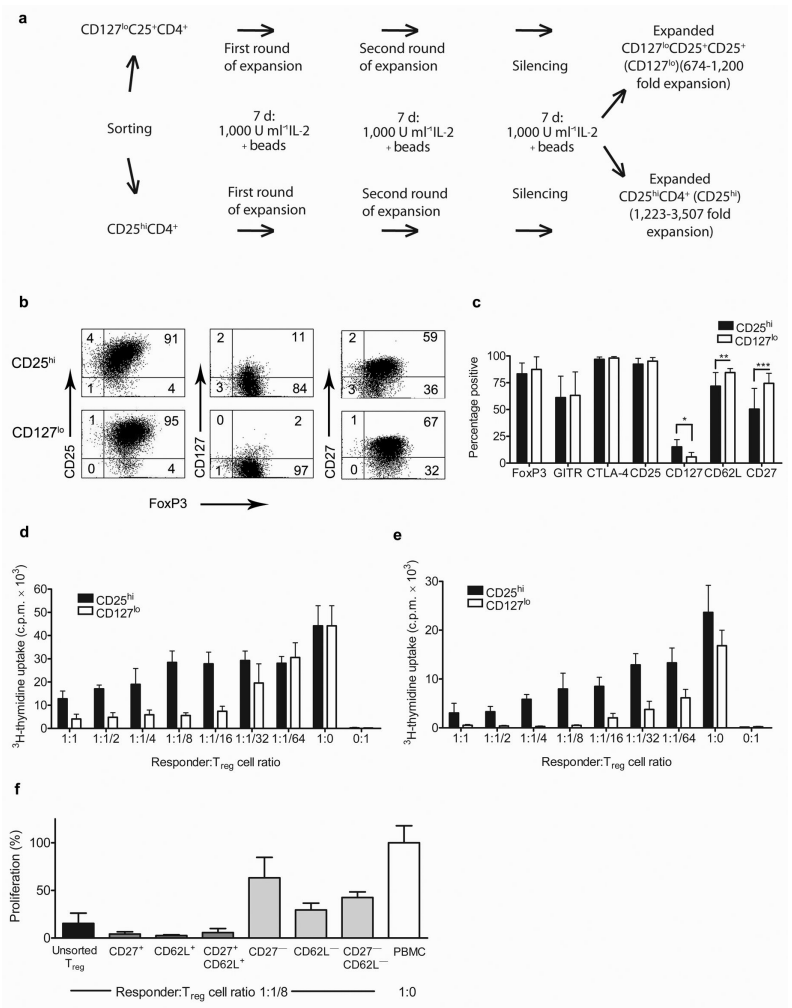

Figure 1. Sorted and ex vivo expanded human $\mathrm{CD} 25^{\text {hi }} \mathrm{CD}^{+}$and $\mathrm{CD} 127^{10} \mathrm{CD}^{+}$cells retain characteristic features of $\mathbf{T}_{\text {reg }}$ cells and differ in suppressive activity in vitro (a) Schematic representation of the expansion protocol and (b) a typical staining of CD25 hi and $\mathrm{CD} 127^{\mathrm{lo}}$ populations from the same blood donor is shown. (c) Expression of FOXP3, GITR, CTLA-4, CD25, CD127, CD62L and CD27 after cell expansion is depicted. The graph represents the percentage of cells positive for each indicated marker. * $P=0.004 * * P$ $=0.0128 * * * P=0.0218$. (d) Autologous PBMC or (e) ex vivo expanded CD25-CD4 ${ }^{+} \mathrm{T}$ cells were co-cultured with irradiated allogeneic PBMC and serial dilutions of expanded $\mathrm{T}_{\text {reg }}$ cells. Data for cells expanded from the same blood donor are shown, with 4 replicates per test. (f) Expanded $\mathrm{T}_{\text {reg }}$ cells were sorted for CD27, CD62L or both markers and cocultured with autologous PBMC and irradiated allogeneic PBMC (as in c). Results are expressed as a percentage of allo-stimulated PBMC proliferation. Error bars in all panels represent the means \pm s.d. 

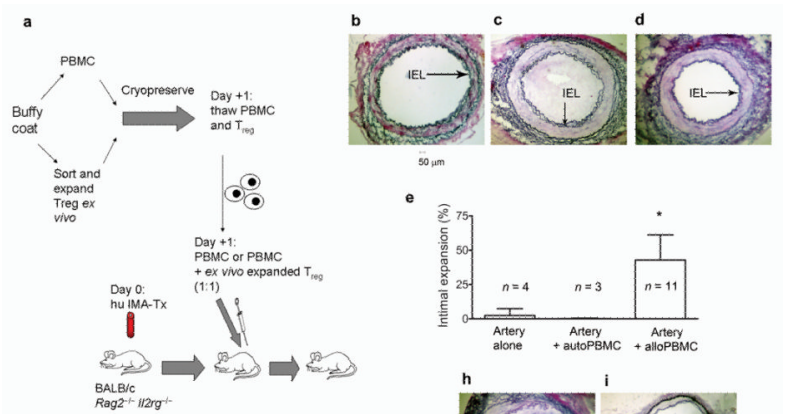

$50 \mathrm{~mm}$

e
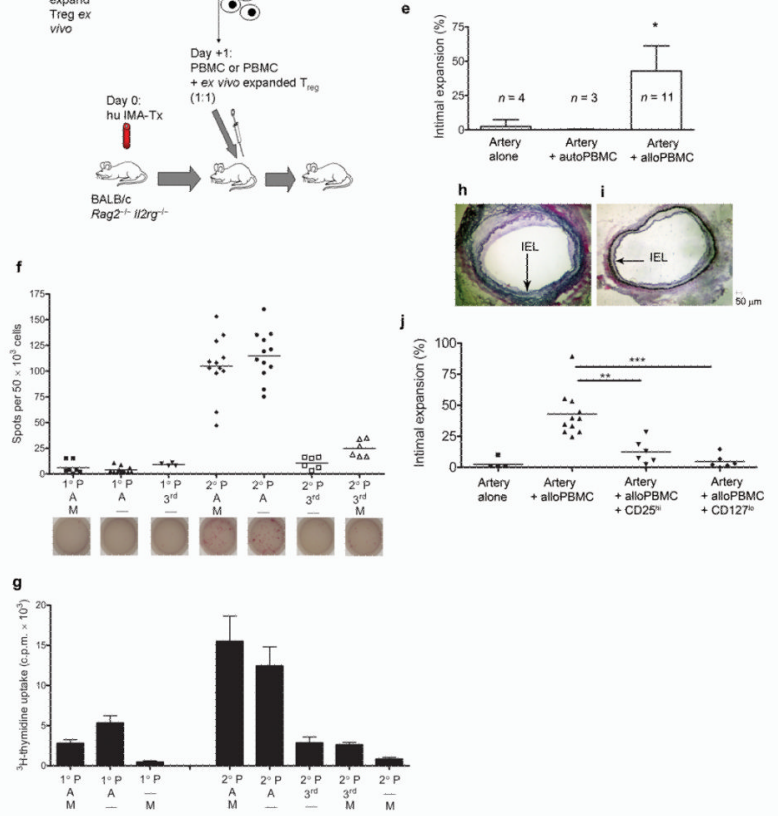

Figure 2. TA mediated by allogeneic human PBMC in human arterial interposition grafts is attenuated with human $T_{\text {reg }}$ cells

(a) A schematic representation of the in vivo protocol. (b-d) EvG staining of a human artery procured from mice transplanted with an artery alone and not reconstituted with PBMC (b); or reconstituted with either $10 \times 10^{6}$ allogeneic human PBMC (c) or $10 \times 10^{6}$ autologous PBMC taken from the arterial donor (d). (e) Percentage of intimal expansion in human arteries from all experiments. (f) Results of ELISPOT for human IFN- $\gamma$ and (g) MLR performed with cells from both the primary $\left(1^{\circ}\right)$ and secondary $\left(2^{\circ}\right)$ cultures $(\mathbf{f}$ and $\mathbf{g}, 2$ independent experiments with $\geq 4$ replicates; $\mathrm{P}$ denotes responding PBMC, A - irradiated allogeneic PBMC, $3^{\text {rd }}$ - irradiated $3^{\text {rd }}$ party PBMC, M - irradiated mouse splenocytes). (h,i) EvG staining of human artery procured from mice inoculated with PBMC $+C D 25^{\text {hi }} \mathrm{T}_{\text {reg }}$ cells $(\mathbf{h})$ or PBMC + CD127 $7^{\text {lo }} \mathrm{T}_{\text {reg }}$ cells $(\mathbf{i})$ at a 1:1 ratio $\left(10 \times 10^{6}\right.$ cells $)$. Histological quantification of intimal expansion in mice treated with $\mathrm{T}_{\text {reg }}$ cell therapy $(\mathbf{j})$. Error bars are represented as means \pm s.d. $* P<0.02$ in the artery + allo-PBMC group when compared to controls, $* * P=0.0013, * * * P=0.0007$. IEL denotes internal elastic lamina. 

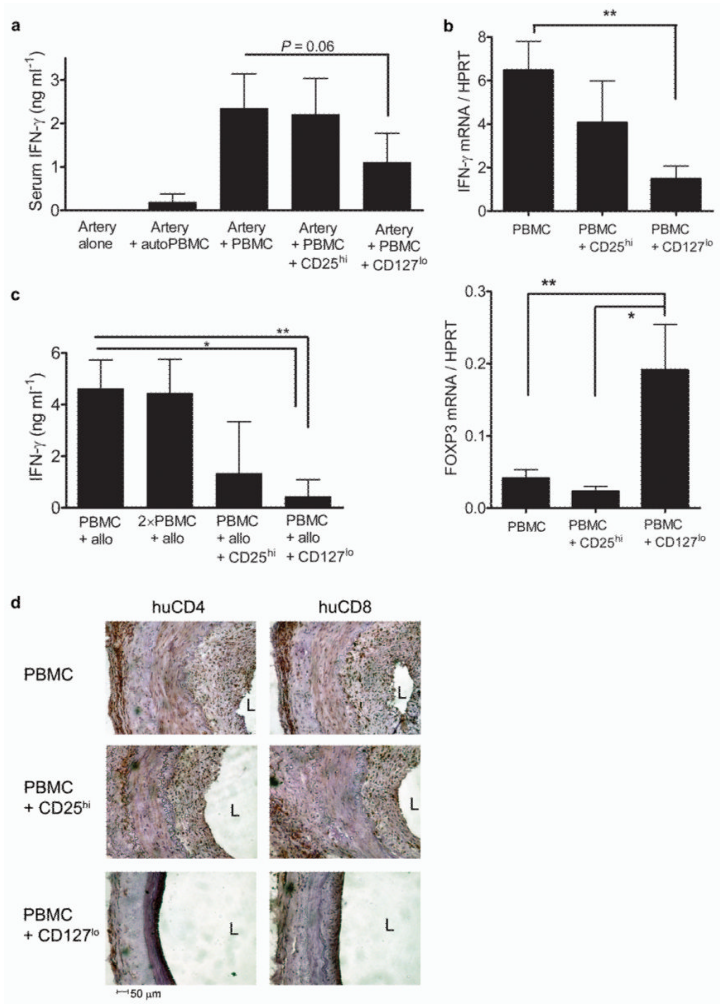

Figure 3. $T_{\text {reg }}$ cells impair effector cell function

(a) ELISA for human IFN- $\gamma$ performed on serum samples harvested from mice transplanted with an arterial graft reconstituted with allogeneic PBMC in the presence or absence of $e x$ vivo expanded CD25 $5^{\text {hi }}$ or CD127 $7^{\text {lo }} \mathrm{T}_{\text {reg }}$ cells. (b) Expression of IFN- $\gamma$ and FOXP3 mRNA measured by real-time RT-PCR in transplanted grafts from mice inoculated with allogeneic PBMC or allogeneic PBMC and $\mathrm{T}_{\text {reg }}$ cells $(n=4-6, * P<0.05 * * P<0.01)$. (c) Human IFN$\gamma$ ELISA on supernatants from cultures of PBMC 5 days after stimulation with irradiated allogeneic PBMC in the presence or absence of $\mathrm{T}_{\text {reg }}$ cells $(* P=0.0260 * * P=0.0022)$. (d) Infiltration of human CD4 and CD8 T cells into the adventitial and neointimal layers of the arterial grafts in mice reconstituted with allogeneic PBMC alone or PBMC and $\mathrm{T}_{\text {reg }}$ cells. ( $n$ $=3$ separate experiments; $\mathrm{L}=$ lumen). Error bars represent the means \pm s.d. 

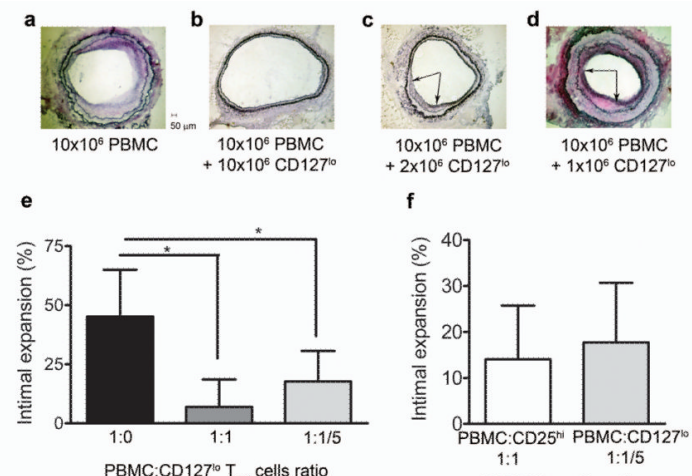
f
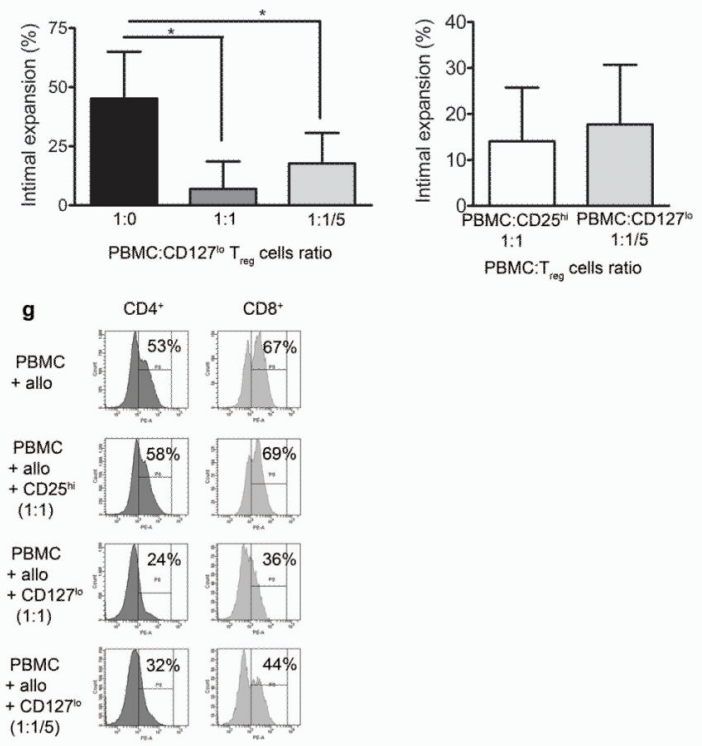

$\overrightarrow{\mathrm{FN}-\mathrm{Y}}$

Figure 4. Ex vivo expanded CD127 ${ }^{10} \mathbf{T}_{\text {reg }}$ cells are more potent than $\mathrm{CD}^{2} 5^{\mathrm{hi}} \mathbf{T}_{\text {reg }}$ (a-d) Representative EvG staining of human arterial grafts from mice reconstituted with 10 $\times 10^{6}$ allogeneic PBMC (a, $\left.n=9\right)$, with PBMC $+10 \times 10^{6} \mathrm{CD} 127^{\text {lo }}$ Treg (1:1 ratio) $(\mathbf{b}, n=$ 7), with PBMC and $2 \times 10^{6} \mathrm{CD} 127^{\mathrm{lo}} \mathrm{T}_{\text {reg }}(1: 5$ ratio $)(\mathbf{c}, n=3)$ and PBMC $+1 \times 10^{6}$ $\mathrm{CD} 127^{\mathrm{lo}} \mathrm{T}_{\text {reg }}$ cells $(1: 10$ ratio) $(\mathbf{d} ; n=3)$. (e) Calculated percentage of intimal expansion at different PBMC to CD127 $7^{\text {lo }} \mathrm{T}_{\text {reg }}$ ratios $(* P<0.05)$. (f) Percentage of intimal expansion at 1:1/5 PBMC to CD127 ${ }^{\text {lo }} \mathrm{T}_{\text {reg }}$ ratio compared to PBMC with CD25 hi $\mathrm{T}_{\text {reg }}$ at a $1: 1$ ratio $(n=$ 4). (g) Intracellular IFN- $\gamma$ production in $\mathrm{CD}^{+}$and $\mathrm{CD} 8^{+} \mathrm{T}$ cells from in vitro cultures of $\mathrm{PBMC} \pm \mathrm{T}_{\text {reg }}$ cells ( $n=3$ independent experiments). Error bars represented as standard deviations. 